\title{
Ethics as Limits of Pedagogical Reflection'
}

\section{Wilfried Lippitz \\ Deutsches Institut für Fernstudiën, University of Tübingen}

These eyes must never become your measure, and if you should ever come to experience me as such an eye, then I ask you ... to forget me. You should penetrate beyond the eyes which fix the events, which classify your childhood as a mere phase of development. (Kolleritsch, 1986, p. 79)

This brief passage from a father's letter to his 16-month-old child seems to be advice to himself as to how to manage his relationship with his son. And it is advice to his son too, to help him fulfill his advice to himself. Both pieces of advice are somewhat strange compared with how we usually think about the educational relationship between father and son, parent and child, or teacher and student.

First, the father does not want to fix his child's being with his own values and expectations. To look at your child in the way you want him or her to be is to measure the child and to compare him or her with more or less impersonal and imposed standards and norms. This means, however, that the child is regarded not in a direct, but an indirect, way so that the child loses his or her uniqueness. In other words, the relationship needs to be immediate. Second, the father seems to feel that he may fail fulfilling this relationship. Therefore, he needs help from his child, and so he advises the son to go beyond the measuring eyes to reach the realm of immediacy between each other.

Thus the father aims for a relationship which transcends any form of unlinear influential power. Like many educational theorists he seems to regard the main characteristic of the educational relationship as asymmetrical. And he recognizes a helping capability that the child can offer the parent or educator.

But can this kind of relationship be called an educational one in the way we conventionally think about it? Or does the father inadvertently seem to give up the idea of education entirely? In an conventional sense education means to be responsible for children by protecting them from danger, by providing them 
with values, and by giving direction to their lives. This is generally considered to structure the relationship in an intentional manner. And our educational system too is a highly intentional system of comparing, mediating the personal relationship by general norms and standards. So it seems that education cannot at all be freed of the intentional structure by making the child independent of the educator's views and aims. Every ethical justification for education seems to depend on this sense of intentionality. From this conventional point of view, the father's advice to himself and advice to his child sounds more than strange. The advice seems to be unreal, out of this world.

In this article I want to show at the hand of the French philosopher Levinas' $(1987,1983)$ concept of ethic that the father's advice $i s$ in a deep sense "unreal," and that it is concerned with the conventional meaning of educational intentionality. But for Levinas the advice and the "notion" of immediacy point to the essential meaning of ethical responsibility experienced as an ethical event. Therefore, I begin by formulating the main points of Levinas' concept of ethics and then develop these insights into an exemplification of the terms of the pedagogical relation and of the nature of pedagogical responsibility.

\section{Formulation of the Problem in Levinas' Ethics}

Let us leave our initial concern with the pedagogical relationship aside and ask with Levinas the fundamental question: Can there be an ethical relationship between myself and the Other who comes upon me, unforeseen, as a stranger? And, given the possibility of that relationship, what would be the bond connecting me with this Other obligating us to each other, calling me to responsiveness in the face of him or her? Am I at all justified in using these questions as a springboard for a discussion on ethics?

Levinas' answers to these questions would not fit into any familiar conception of moral philosophy and moral pedagogy: He would say that ethics occurs as a situation which befalls me as subject. $I$ happen into the immediate vicinity of the Other, who is and remains absolutely foreign to me. Nonetheless, $I$ become responsible for him or her; he or she exercises an ethical claim on me which articulates itself without reference to any given obligation-be it a common value system encompassing and transcending us; a sociocultural order or language working through us and thus connecting us; a universal moral rationality which transcends our respective individualities; or a relation of dialogue, founded in a common origin of reference, encompassing both me and you. 
A constituent part of ethics is the absolute separation between myself and the Other. Heterogeneity, not unity or reciprocity, is the characteristic of the ethical situation. In this situation I, as the only subject, am irreplaceable. Levinas' ethical philosophy is thus a philosophy of subjectivity, but at the same time a philosophy of the transcendence of the Other, who bursts open the self-possessed composure of subjectivity from the inside. Levinas' philosophy breaks with the "intentional" composedness conceived by the thought of a philosophy of consciousness, but it also moves in a sphere beyond "Being and Time," beyond the ontology of Being. As an event, the ethical situation can never be integrated into a categorical system: It is anarchic. As an "incident," unforeseen and unplanned, it is preintentional. Compared with the incident, ethical consciousness and knowledge always come too late: They are anachronistic. Yet the ethical situation supposedly obligates me to the Other and renders an experience possible the identity of which must be established in view of traditional ethical thought. How is this to be accomplished if traditional systems of thought and conceptions do not even suffice for the purpose of description?

Levinas (1983) realizes this problem. Ethical language, he says, comes from what one calls nonphilosophical experiences, experiences which differ from knowledge and which refuse to be ordered into a philosophical system. Hence he continues in his expressive, richly metaphorical way, "Language's clutching for the anarchic ... is the pain and struggle for expression" (p. 319). The difference between linguistic expression and intended meaning is insurmountable.

The ethical relation, which we can only experience internally, "only ... to the extent to which we act it out (Levinas, 1987, p. 45) sets the standard for the way of thinking about it. Thus paradigmatic situations of ethical experience (the countenance of the Other, the situation of hostage-taking and persecution by the Other, the ethical gesture, and so on) provide an important means of theoretical reflection for Levinas as well as the foundation for his philosophy. I too would like to use a paradigmatic situation to elucidate the position of Levinas' ethics, for which I have up to this point only given an abstract outline.

\section{The Otherness of the Other}

There is a play by Pasolini, not often performed, which bears the title Calderon. The play is about the latent and manifest coerciveness of human relations, a phenomenon which extends into the intimate realm of family relationships and perpetuates itself there through the generations in an almost eerie cycle. The 
opening scene, which is repeated several times throughout the play, is significant for our theme: A sleeping woman lies in bed. She awakes suddenly and sees another woman sitting next to her. The waking woman is taken aback. She recognizes neither the surroundings nor the other woman. The origin and sociocultural style of the furniture is unfamiliar to her. She no longer even knows her own name. It is as if not only her own identity has been wiped out, but also her ability to decipher the significance of the world around her, to understand something as something. She is a stranger to herself in a foreign land. The loss of the familiar world is the loss of identity. In her distress she turns to the other woman, who reacts with alarm. This woman's alarm mounts to displeasure and finally aggression as the woman seeking help fails to concur with any of her attempts at identification. Sartre would say: The waking woman refuses to be the person the other designates her to be. She does not recognize herself as the other woman's sister or as the member of a certain family and of that family's tradition. She does not even recognize herself in the activities that are supposed to be typical and unmistakably characteristic of her.

The sister's aggression springs from her own shaken security and points to an identity crisis threatening to engulf her, for the foreignness of the person closest to her, in this case her waking sister's insistence on her own foreignness, disrupts the familiarities and certainties of everyday social life and thus the certainty of her own self. What can the sister do to remedy this situation? She and the family submit the one who has become foreign to an educational process: They force her to learn who she is. They foist an identity on her so that her Otherness as Other, her foreignness, and with it the disturbance of conventional order, disappears. The erstwhile Other becomes a marionette at the mercy of the ruling order. The other is conformed, she is given a mere part of a given whole. She becomes faceless, insignificant, unobtrusive.

In terms of Levinas' ethics, this situation has a paradigmatic character. The constellation portrayed in the opening scene is -in terms of its structure ethical to the core. It is also social: In it the conditions for the constitution of intersubjectivity become clear. Its structure is heterogeneous, for it assumes the radical separation of the interacting parties and thus acknowledges their respective uniqueness and otherness. The scene dramatizes the foreignness of the Other, who is my neighbor (in the indirect and figurative sense of the word) in the midst of a world which is familiar to me. The scene brings out the nonidentifiability of the Other, who by virtue of his or her foreignness 
evades my attempts to make the Other into the likes of me, into someone I already know. In the terminology of Levinas, the scene portrays the nonidentity, the nonidentifiability of the Other, the vulnerability revealed in his or her exposed, naked countenance. The dire need of the foreign one stems from the fact that he or she does not belong to any standing order; the Other is lawless and homeless and therefore implores me for my help. This request, this appeal, is direct and immediate; it is intended solely for me and for no third person. It penetrates directly to the core of my identity, my self-consciousness; it decentralizes me and charges me with an undesired, unforeseen burden which I had not included in my plans. However, this situation with the Other is also the greatest opportunity for me to free myself from the constant, oppressive concern with my own existence. ${ }^{2}$

The sister of the waking woman misses this opportunity. The family's "re"-education program and the methods of identification and discipline they use are not the free play of an unrestrained will, but rather are themselves dictated by an oppressive ruling order. Pedagogy takes place here as a process of estrangement of the strange. It avoids the direct look that subjects itself to the look of the Other. In the words of Levinas (1987):

Our pedagogical speech is rhetoric, speech from the position of him who outwits his neighbor ... it does not address the Other face to face, but from the side ... the specific nature of rhetoric ... consists in corrupting freedom. It is therefore a distinct form of might, i.e., injustice. (p. 95)

It appears quite obvious that the ethical relation, the face-toface relation, occurs outside the pedagogical relation. It is, moreover, the opposite of the pedagogical relation.

This sounds familiar. Colonization, discipline, and friendship in lieu of pedagogy, the latent and manifest coerciveness of immediate pedagogical-practical comprehension and of the scientifically disciplined culture of comprehension-all these catchphrases express a general mistrust toward our culture of scientific experts. They signal the crisis of modern rationality, the challenge to the ethical and moral legitimation of modern rationality.

This context throws a dubious light on the moral-pedagogical discussion in educational theory which has once again become a topic of interest. Despite the diversity of concepts, the discussion appears to boil down to one and the same: the abolition of individuality in favor of equality, however it may be produced, 
under the cloak of a normative system. Under this cloak belong, on the one hand, conservative moral philosophy, on the other, Kohlberg's concept of moral development, which is allied to the powerful Kantian tradition of rationally grounded morality.

Does not Kohlberg's conception (Gilligan, 1982), by virtue of its grounding in principals and its universalistic, logocentric orientation, also ignore the incomparability of ethical subjects and, furthermore, the ethical claims which only arise in concrete situations and for which there is no common, prejustifiable standard?

We do not have to refer back to Levinas in order to prove the problematic nature of this question. Gilligan's vehement attack on the Kantianism in Kohlberg's concept of moral development aims, at the fundamental level, not so much at the gender-specific difference of a male or female morality than, in Gilligan's own opinion, at a different, alternative conception. Her interviews, which are geared toward examining the existential moral conflicts of female subjects and not merely toward analyzing problematic thought processes removed from reality, clearly reveal that the women tend to base their reasoning not on principles, but rather on situation. Their argumentation is more "concrete" because they feel obligated to the Others in their lives. The Others speak, as it were, through the women more than the women speak themselves; the women show more consideration for the vulnerability of the Others than for their own interests.

Gilligan interprets this trait on the one hand as a special virtue, on the other as a symptom of a lack of ego-strength and an inadequate articulation of need. But Levinas sees this "non-selfreference" in moral argumentation as entirely positive; he understands it as generosity and patience (Levinas, 1987, p. 202). These qualities comprise an ethical attitude which I do not choose of my own free will, but which is made possible to me by the Other: I bear the burden of the Other with which he or she charges me; I perceive the Other's need of which I am not the originator, and I expect no gratitude. The gratitude of the Other as an expected reciprocity would be an act which would refer back to me; it would be reduced for the Other to a means, a way-station. In that case the Other would no longer be the one who would liberate me from solitude and from the burden of self-referential activities.

But please do not misunderstand me: When I illuminate Gilligan's position by means of Levinas' methods, I am not pleading for a patriarchal, male morality which lives on female 
self-sacrifice. Levinas' intent is precisely to denounce all forms of domination as the "running astray" of western thought and action. For this reason $I$ think it is legitimate to venture a discussion which calls attention to the exceptional nature of the women's argumentation. It calls attention to an understanding of morality that does not fit into any kind of domination-subordination dialectic.

Let us turn back to the opening scene of Pasolini's Calderon. The problem of the awaking woman is her loss of identity. She has fallen out of the ruling order. Or, to put it differently, she is like a newborn child: She does not yet belong to any ruling order through which she is identifiable in that she identifies with it. Yet, like the newborn, she already has meaning in a unique, concrete way: as a countenance void of any kind of categorical or classifiable structure. Levinas (1987) speaks of "imageless sight" (in the sense of the Jewish prohibition of images of God) as an ethical act. "In every moment the countenance of the Other destroys and inundates the graphic image it leaves with me, it exceeds the idea that it is according to my standard and the standard of its 'ideatum'-the adequate idea" (p. 63). The Other is transphenomenal. He or she has no presence, not even in the weak form of appresentation as in Husserl, in which the living body facing me indicates another consciousness as a consciousness different from and yet analogous to me. The ethical experience can never be described in terms of a power of recognition and perception oriented to presence and evidence; it exists beyond the bounds of recognition. The ethical situation is asynchronic: I always come too late, or, to put it differently, I always lag behind. In ethical terms I always have a guilty conscience, because I lag fundamentally behind the appeal the Other directs at me. His or her helplessness is my helplessness, for I cannot arm myself for the ethical situation. As subject in the ethical experience I am robbed of my initiative, or rather I am-in the literal sense of the word-subject to the Other. He or she impacts me (grammatically speaking, not accusatively) in the center of initiative of the first person.

Thus there is no symmetry in the ethical experience. I am not an equal partner, but-as Levinas calls it-I am the hostage of the Other, "at his mercy and subjugated to him" (Levinas, 1983, p. $372 \mathrm{ff})$. That I experience the Other as a stranger, not as the likes of me, that I therefore break out of the circle of my own self-relation, my concern with myself, reveals that the ethical situation gives me more than I am capable of on my own. The Other enables me to do more than I can do. 
Seen in this way, the Other is my master (maitre). Here, therefore, in the passivity of the apprentice, in this asymmetry, is where the pedagogical dimension of the ethical relationship unexpectedly reveals itself. It is the need of the Other, his or her helplessness, which brings me out of myself and to which I respond with empty hands in order to receive him or her. It is a selfless act of impotence of capacity. In this relation I owe a debt to the Other which I myself can never repay. For the difference between myself and the Other as a stranger remains the condition for the possibility of the ethical relation. My obligation to the Other articulates itself in this debt; this is the bond about whose possibility I initially inquired. I am consequently not free from the beginning to decide for or against the appeal of the Other. ${ }^{3}$ The sister in Pasolini's play does not have the choice from the outset of whether to perceive the ethical claim of the one who has become a stranger. Her decision in the face of the appeal always comes too late, it is already ethically founded, but it is not founded as a result of the autonomy of a free being. The welling aggression signals the identity crises of an ego defending itself against being possessed by the Other, a possession which has actually already taken place; the Other has already triggered a sense of alarm inside the subject. Thus there is no preethical posture toward the ethical. If you refuse the ethical claim then you double your debt and you fail to realize the possibility of liberation from the concern over oneself.

At this point I can only briefly indicate that Levinas (1983) uses a theory of the body to support the structure of intersubjectivity alluded to here as an ethical structure of a solidarity in the heterogeneity of the partners. The body is the embodiment of my vulnerability and exposedness, the location of the pains to which I am subject, the place where-without any action on my part and without having the chance to take initiative or control-time leaves its traces behind as aging (p. 308ff). It is my time that passes. But it passes in the paradoxical manner of a time for which I, as consciousness, as knower, come fundamentally too late. It is already my past when I attempt to set myself in relation to it. Here, at these bodily instances, an original passivity of the subject becomes visible which Levinas characterizes with the term "creature-ness," the subjecthood of an unmistakable individual who has no control over his or her own beginning nor over his or her end, who is permeated to the depths of his or her own existence with passivity-not, however, a passivity of senselessness, but of the possibility of opening up to the Other. This is true not only for the ethical relation, but also for aging. Aging and death present the chance for a mortal being to have a future beyond death, a future which is his or her 
own in that it does not belong to him or her. It is the future of the "son" in the biblical terminology of Levinas. It is, in other words, generativity, fertility.

\section{Fertility (Levinas, 1987, p. 318ff.)}

As for Schleiermacher (1966), the intergenerative relationship is an ethical problem for Levinas. Let me recall the general "ethical question" in Schleiermacher's introduction to his pedagogical lectures of 1828 . If the structure of the pedagogical act consists in the fact that each pedagogical intervention is the sacrifice of one specific moment for the sake of a future one, then the ethical problem is: "Is one permitted at all to allow the sacrifice of one moment in life as mere means to another, different one" (p. 46)? Schleiermacher's solution prefers a model of reciprocity which amounts to a somewhat moderate relationship of continuity between the generations. All education is geared toward the future. It is the "ethical task in the relation of the whole to the individual" (p. 48). The art of education, then, consists in bringing the "essence of the human being ... more completely" to the fore "in each moment of life" and within the framework of "membership in a common greater domain of human life" (p. 48). Schleiermacher describes this process as "penetration of the difference between presence and future." The formulation of the "more complete emergence of the essence" (p. 48) implies a teleological instance, for one can only perceive the possibilities of enhancing individual life from the perspective of a successfully completed educational process. To speak of the "penetration of the difference" which increases accordingly "the less the one is sacrificed to the other" shows the generational process as a reciprocal relationship of exchange of the new with the old, of the specific with the general (Schleiermacher, 1966, p. 48). The exchange creates an evenness and thus helps to preserve the continuity between the generations. In this manner the difference is leveled out. The generations prove to be coordinated with each other.

Levinas, in contrast, radicalizes the difference. In his biblical language it sounds like this: The future of the "son" is not the future of the "father," and it is by no means integrated into the "father's" present as an educational plan or as some other form of anticipation. ${ }^{4} \mathrm{It}$ is only the discontinuity between the generations which ensures that history does not repeat itself compulsively as old history, but rather is able to happen as something radically new and unforeseen. There is no common tie between present and future. The supersession of one generation by the other occurs radically. Seen in this way, "fatherhood" is an adventure. "My son is a stranger, but he not only belongs to me, 
he is me. I who am foreign to myself am the son myself (Levinas, 1987, p. 39). The child is not me, because he or she is not my work, because this child cannot be begotten by me alone. The love for a woman is necessary for this. This erotic relationship, however, lives from the dissubjugation of the partner, by a fusion that knows no egocentrism and drives back every subjective capacity. The child born of this is an entity who comes from a future over which I have no control. Fertility, like the ethical relation, has the structure of an impotence of capacity (NichtKönnen des Könnens) which is not initiated by me. The child, continues the parent's time (which the parent as a mortal no longer possesses) by breaking with the parent's time. The parent's being, which the child continues in a different way, is not a substance, not an Eleatic being; it is a process, "transsubstantiation." In this way I am to a certain extent my child without having this child. Through the child I am an Other, who continues my time, inaccessible to me, as my future (Levinas, 1987, p. 400).

The child who in his or her way is able to do what I cannot, because he or she outlives me, enters into an elementary ethical situation: He or she can, representing the parents, bear and forgive the burden of debt for which they as mortal beings can no longer be responsible. The parents bear their destiny in their children as a different destiny. Thus the radical difference between parents and children has an ethical structure. The children literally represent the power that the parents cannot produce, of taking responsibility for the parents' lives when it is too late for them.

The pedagogical relation reveals itself from an unexpected, different aspect in view of the familiar phrase "children are our future." They are our future indeed, but only as their present, which has nothing in common with ours. I myself do not have the power to forgive myself; only someone who is not me can do that. Like the ethical, the intergenerative relation reveals the rift which is the foundation of human existence (Reiter, 1984, p. 368 ), the rift running through human existence. To grasp the fragmentation of human existence revealed in this rift as the opening for the Other and the Other's time, to understand it as liberation from the self-centered anxieties driving me round in a closed circle of self-reference, to see it as liberation from everything totalitarian threatening to overwhelm me, to conceive of this liberation radically is the goal of the new foundation of ethics by Levinas. 


\section{Conclusion}

The initial questions of this discussion aim at grounding the standard of reference for pedagogical responsibility. Levinas' radical attempt at founding a system of ethics as a primary philosophy shows that my responsibility springs from an obligation brought about by the Other, who acts as my master (maitre). He or she enables me to do what I am not able to do myself: to discover myself as an $I$ in my responsibility for the Other, to step out of the maelstrom of my own self-referential, economic existence. Thus the establishment of a pedagogical responsibility ensues from the internal pedagogical dimension of the ethical relation. In other words, the Other, the stranger, the child is the condition for the possibility of my pedagogical activity. The child is my task-giver in the framework of a relation not marked by the mechanisms of self-preservation and foreign rule.

\section{Acknowledgments}

I thank Mrs. Loreen Unruh for her translation, respecting the author's style of writing, and Max van Manen for his advice for improving the manuscript.

\section{Notes}

1. This essay is the abridged version of my "Von Angesicht zu An. gesicht. Überlegungen zum Verhältnis von Pädagogik und Ethik im Anschluss an Levinas" (Face to face. Reflections on the relation of pedagogy and ethics in connection with Levinas), Vierteljahresschrift für wissenschaftliche Pädagogik, 65 (1989), 266-281.

2. Compare the concept of Being and Existence which emphasizes the burdensome character of an existence threatened with fading into an anonymous Being, Levinas, (1984) p. $21 \mathrm{ff}$.

3. Compare the concept of freedom, especially Levinas (1983) p. 314. Every responsibility exists prior to freedom.

4. There obviously is an issue of gender bias associated with Levinas' patriarchal language use. However, rather than doing violence to the substance of his thinking I maintain the original phrasing of the "father-son" metaphor to stand for the ethical situation of all human beings.

\section{References}

Kolleritsch, A. (1986). Lieber Sohn Julian! (Dear Son Julian). In H. Haidler (Ed.), An mein Kind. Briefe von Vätern (To my child. Letters from fathers). Munich: dtv-pocket book.

Gilligan, C. (1982). In a different voice. Cambridge, MA: Harvard University Press.

Levinas, E. (1983). Die Spur des Anderen. (The trace of the Other). Munich: Albers. 
Levinas, E. (1984). Die Zeit und der Andere. (Time and the Other). Hamburg: Meiners.

Levinas, E. (1987). Totalität und Unendlichkeit. Versuch über die Exteriorität (Totality and infinity. A treatise on exteriority). Munich: Albers.

Schleiermacher, F. (1966). Die Vorlesungen aus dem Jahre 1826. Einleitung. (The lectures from 1826. Introduction). In E. Weniger (Ed.), F. Schleiermacher. Pädagogische Schriften (2nd ed.). Paderborn: Schöningh.

Reiter, J. (1984). Der "Humanismus des andern Menschen." Eine Einleitung in das Denken von Emanuel Levinas. (The humanism of the other human: An introduction to the thought of Emmanuel Levinas). Theologie und Philosophie, 59, p. 38. 